\title{
Print media coverage of California's smokefree bar law
}

\author{
Sheryl Magzamen, Annemarie Charlesworth, Stanton A Glantz
}

\begin{abstract}
Objective-To assess the print media coverage of California's smokefree bar law in the state of California.

Design-Content analysis of newspaper, trade journal, and magazine items.

Subjects-Items regarding the smokefree bar law published seven months before and one year following the implementation of the smokefree bar law (June 1997 to December 1998). Items consisted of news articles $(n=446)$, opinion editorials $(n=31)$, editorials $(n=104)$, letters to the editor $(n=240)$, and cartoons $(n=10)$.

Main outcome measures-Number and timing of publication of items, presence of tobacco industry arguments or public health arguments regarding law, positive, negative, and neutral views of opinion items published.

Results- $53 \%$ of items published concerning the smokefree bar law were news articles, $47 \%$ were opinion items. $45 \%$ of items regarding the smokefree bar law were published during the first month of implementation. The tobacco industry dominated coverage in most categories (economics, choice, enforcement, ventilation, legislation, individual quotes), except for categories public health used the most frequently (government role, tactics, organisational quotes). Anti-law editorials and letters to the editor were published more than pro-law editorials and letters. Region of the state, paper size, presence of local clean indoor air legislation, and voting on tobacco related ballot initiatives did not have an impact on the presence of opinion items.
\end{abstract}

Conclusions-The tobacco industry succeeded in obtaining more coverage of the smokefree bar law, both in news items and opinion items. The tobacco industry used historical arguments of restricting freedom of choice and economic ramifications in fighting the smokefree bar law, while public health groups focused on the worker protection issue, and exposed tobacco industry tactics. Despite the skewed coverage, public health groups obtained adequate attention to their arguments to keep the law in effect.

(Tobacco Control 2001;10:154-160)

Keywords: content analysis; politics; passive smoking; smokefree bar law; California

The California Smokefree Workplace Law (AB 13) was implemented in public and private workplaces and restaurants on 1 January 1995 , and in bars, taverns, and gaming rooms on 1 January 1998 to create the first state wide smokefree bar law. ${ }^{12}$ Public health advocates were able to enact this law and defend it against tobacco industry efforts to repeal it, in part by engaging the public through the media and using this public pressure to influence the state legislature..$^{2-9}$ The media served as a vehicle for dissemination of information concerning the law, provided the general public and key decision makers with a sense of progress in implementing the law, and served as the primary public forum for the debate about the efficacy, necessity, and impact of the law.

The media plays two primary roles in the policy making process: to inform the public of pertinent issues at the time, and to shape public thought about these issues..$^{10-12}$ Framing is the process by which groups of facts are packaged to create a story through images and symbols, use of selected spokespersons or organisations for information or opinions, specific language, and the amount of attention devoted to the issue. ${ }^{11}$ In debates over clean indoor air laws, tobacco control advocates frame the issue in terms of the need to insure public safety (protecting people from secondhand smoke $^{9}$ ) and the low credibility of the tobacco industry. ${ }^{11}$ The tobacco industry frames the issue as restrictions on adult freedom of choice, economical damage to bars, and unnecessary government interference..$^{13} 14$

Both public health advocates and the tobacco industry sought to influence the coverage of the smokefree bar law. Tobacco control advocates, including voluntary health organisations and local health departments, held press conferences, released polls showing public support for the law, and used grassroots networks to write letters and visit editorial boards. $^{5}$ The tobacco industry primarily worked through the National Smokers Alliance, which the public relations firm Burson Marsteller created for Philip Morris tobacco company. ${ }^{15} 16$ In addition, Burson Marsteller issued over 70 press releases over a six month period of time (approximately one every three days) over PR Newswire, a pay-for subscriber media service. ${ }^{5}$

This study analyses the print media coverage of the California Smokefree bar law, from seven months before and one year after the implementation of the law. We assess what was stated and reported in the print media about the smokefree bar law, who provided the information for the 
Table 1 Smokefree bar law media framing categories

\begin{tabular}{|c|c|c|}
\hline Theme & Tobacco industry frame & Health groups frame \\
\hline Economic & $\begin{array}{l}\text { Hurts business } \\
\text { Decreasing revenues and tips }\end{array}$ & $\begin{array}{l}\text { No negative effects/good for } \\
\text { business } \\
\text { Usual adjustment period }\end{array}$ \\
\hline Choice & $\begin{array}{l}\text { Smokers' rights } \\
\text { Adult choice }\end{array}$ & $\begin{array}{l}\text { Non-smokers' rights } \\
\text { Public supports the law }\end{array}$ \\
\hline Enforcement & Inconsistent/no enforcement & $\begin{array}{l}\text { Enforcement is going well/being } \\
\text { worked out }\end{array}$ \\
\hline Government role & Government interference & $\begin{array}{l}\text { Government role to protect } \\
\text { employees }\end{array}$ \\
\hline Ventilation & Need to create state standards & No standards would be sufficient \\
\hline Legislation & Bills to repeal or delay law & Attempts to uphold law \\
\hline Tactics & Attack academic/economic studies & $\begin{array}{l}\text { Attacking tobacco industry } \\
\text { credibility }\end{array}$ \\
\hline Civil disobedience & Purposefully disobeying law & - \\
\hline Patron habits & Drinking and smoking go together & - \\
\hline Workplace hazards & $\begin{array}{l}\text { Employees should accept } \\
\text { workplace hazards }\end{array}$ & $\begin{array}{l}\text { Employees should not be subject } \\
\text { to workplace hazards }\end{array}$ \\
\hline
\end{tabular}

news articles, editorials, and letters covering the law, and how these two factors changed over time.

\section{Methods}

We obtained all print media items (news articles, letters to the editor, editorials, opinion editorials (op-eds), and cartoons) that appeared in California publications (daily and weekly newspapers, magazines, and trade publications) related to the smokefree bar law from Burrelle's Information Services. Burrelle's collects all print media items relating to smoking and tobacco in California publications for the public relations firm Rogers and Associates (which is under contract with the California Department of Health Services) using the search terms "tobacco" "cigarettes" and "smoking." Burrelle's estimates that they capture at least of $85 \%$ of items related to the search criteria, ${ }^{17}$ so we considered the items captured to be the entire population of print news coverage, rather than a sample.

Rogers and Associates provided us with the items related to bar, tavern, and gaming rooms: 446 news articles, 240 letters to the editor, 31 op-eds, 104 editorials, and 10 political cartoons. Our population contains items that appeared beginning in June 1997, when Rogers and Associates created a separate category for coverage of smokefree bars, through 31 December 1998, a year after the law went in to effect. Items that appeared on various news services (UPI, AP, PR Newswire) that were not published in a newspaper or trade journal were excluded, since the information was not available to the general public.

All items were classified into one of five categories (news article, editorial, op-ed, letter to the editor, or cartoon). Each item was coded by author, date of publication, type of newspaper or publication (daily, weekly, monthly), and publication title. We used the Gale Directory of Publications and Broadcast Media ${ }^{18}$ to identify the city of publication and circulation of the newspaper. When we encountered a publication that did not appear in the Gale Directory (that is, trade journals and weekly papers), we contacted the publisher for the city of publication, frequency of publication, and circulation. We coded the publications by geographic regions using pre- 1 November 1997 telephone area codes of the city of publication to give us six regions.

Items that appeared in different editions of a single newspaper (for example, the San Diego County North County Times publishes six local versions of the paper) were counted as one item. When the copy provided by the clipping service was incomplete, we contacted the publisher, and searched the microfilm archives at the University California, Berkeley, and the internet for the full item. There were only four instances in which we failed to find the full item; these were excluded from our analysis.

We used previous research on the political battle over the smokefree bar law ${ }^{5}$ to identify the major arguments for and against the law, together with previous work by Menashe and Siege $1^{13}$ and by Cardador and colleagues ${ }^{14}$ to design a coding scheme to classify arguments for and against the law (table 1). We analysed each item for the presence of these arguments, and counted the amount of distinct arguments that appeared in each item, allowing us to quantify the frequency of the appearance of these arguments for all of the items in the analysis. If an argument was present more than once in an item, it received only one "present" code. Opinion items were additionally scored as "pro-law", "anti-law", or "neutral". We did not score news articles in this manner.

Aside from the themes, we also included categories for groups or individuals cited in the items. The anti-law organisational quotes category included cigarette manufacturers, the National Smokers Alliance, and restaurant/ tavern associations. Anti-law individual quotes included bar patrons, employees, employers, politicians, and enforcement officials. The prolaw organisational quotes category included voluntary health organisations, state and local health departments, local enforcement agencies, academic institutions, and unions. The pro-law individual quotes category included patrons, employees, employers, and politicians supporting the law.

The items were coded by two individuals (SM and AMC). To test for consistency, both coders evaluated the same 47 items, selected using a table of random digits. The median agreement (both raters coding a category present or both coding it absent ${ }^{19}$ ) for the 22 categories between the two raters was 93\% (range 81-100\%; interquartile range 84-94\%). The median value of $\kappa$ was 0.74 (range 0.47-1.00; interquartile range 0.63-0.84), excluding three categories in which $\kappa$ was 0 because of a very small number $(<5)$ of positive results. (The per cent agreement for these three categories was $92 \%, 92 \%$, and $92 \%$.)

We wanted to examine whether items that appeared in newspapers were related to the tobacco control sentiment of the communities and regions that they served. We utilised the circulation of the newspaper to approximate the exposure to an argument published in an opinion item, and coded the newspapers by city of publication. We were then able to measure the tobacco control sentiment of each city 
Table 2 Distribution of opinion items on California's smokefree bar law

\begin{tabular}{lllll}
\hline Type of item & Support & Oppose & Neutral & Total \\
\hline Editorial & $41(39 \%)$ & $49(47 \%)$ & $14(14 \%)$ & $104(100 \%)$ \\
Opinion editorial & $17(55 \%)$ & $13(42 \%)$ & $1(3 \%)$ & $31(100 \%)$ \\
Letter to the editor & $96(40 \%)$ & $122(51 \%)$ & $22(9 \%)$ & $240(100 \%)$ \\
Cartoon & $154(41 \%)$ & $181(49 \%)$ & $37(10 \%)$ & $375(100 \%)$ \\
Total & & & \\
\hline
\end{tabular}

by two proxies: presence of a local clean indoor air law, and voting records on a state wide proposition concerning clean indoor air regulations.

To assess whether the existence of a local clean indoor air law before implementation of the state smokefree bar law was associated with coverage of the issue, we examined opinion items (editorials, letters to the editor, and op-eds) published in a specific locality as a function of whether the locality had implemented a general clean indoor air law or a smokefree restaurant law as of 1 January 1995, (when the state Smokefree Workplace Law, was implemented) using the Americans for Nonsmokers' Rights local ordinance database. (Twenty communities had smokefree bar laws in place as of that date, but this number was too small to support meaningful analysis of any possible effect on media coverage of the debate over the state law.) We did a similar analysis based on how the locality voted three years earlier on proposition 188, a 1994 initiative sponsored by Philip Morris to repeal the smokefree bar law and pre-empt all local tobacco control ordinances in California. ${ }^{2}{ }^{3}$ (The vote on proposition 188 provided a direct measure of public sentiment on the issues raised later in the public debate over the implementation of the smokefree bar law.) Public health advocates defeated proposition 188 in all counties in California. We ranked the 112 localities that had opinion items present in its newspapers by margin of defeat, then divided the localities into quartiles (measured by margin of defeat of proposition 188) to assess if there was an association between the tobacco control sentiment and arguments subsequently presented in local newspapers.

All results were tabulated using SPSS 8.0. To assess the number of media impressions (item frequency times publication circulation) for each item, we multiplied the circulation of each publication times the frequency of items using the "weight" function in SPSS. Since we consider the collection of items a census of the population rather than a sample, we did not compute any hypothesis tests or $\mathrm{p}$ values.

\section{Results}

We collected and classified 831 unique items (news articles, editorials, letters to the editor, op-eds, and cartoons) covering the smokefree bar law: 93\% appeared in daily newspapers, $4 \%$ in weekly papers, and $3 \%$ in monthly publications; $14 \%$ of the items appeared in the Sunday newspaper, which is the highest readership day for newspapers, ${ }^{20}$ about $1 / 7$ of all the items; $3 \%$ of the items appeared in trade or professional journals; $19 \%$ of the news articles appeared on the front page, the most

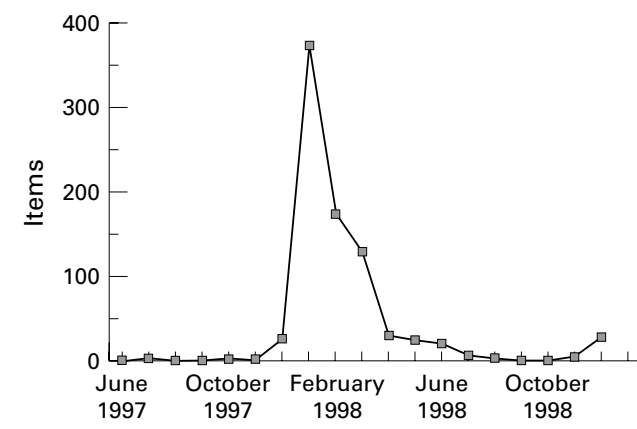

Figure 1 Items present in California newspapers and print publications reached a high in Fanuary 1998, the month the smokefree bar law went into effect. After the state Senate voted to uphold the law in March 1998, coverage of the smokefree law dropped to pre-implementation levels, and only increased slightly again when the law was reaching its one year mark in December 1998.

frequently read page of the newspaper, indicating that the issue of smokefree bars was considered an important topic.

\section{CLASSIFICATION OF ITEMS}

News articles constituted the largest category of items $(446 / 831,54 \%)$. Opinion items included 104 editorials (13\%), 31 op-eds (4\%), 240 letters to the editor (29\%), and 10 cartoons $(0.1 \%)$. Most editorials and letters to the editor opposed the law, whereas op-eds tended to support the law (table 2).

TIMING

Appearance of items about the smokefree bar law was minimal throughout 1997, slightly increased in December 1998, the month before implementation, and reached a peak in January 1998, the first month of implementation (fig 1), when $41 \%$ of all items written about the law appeared. Presence of items about the law remained high for the following two months, and dropped precipitously by April 1998. Coverage continued to decrease throughout the year until December 1998, when there was a slight increase, reflecting stories reviewing the first year that the law was in force.

The frequency of news articles followed the general pattern of frequency of all items. The frequency of opinion items followed different patterns. Opinion items supporting the law started to appear in July 1997, before opinion items opposing the law, which started to appear in December 1997, and peaked in January 1998. Pro-law editorials, letters to the editor, and op-eds reached highest frequency in January 1998, February 1998, and March 1998, respectively.

The timing of the arguments in the individual categories (table 1) followed the general pattern of frequency of all items in fig 1 except in two cases. The tobacco industry's arguments that the law would be difficult or impossible to enforce peaked in December 1997, before the law went into effect, whereas general coverage peaked in January 1998, the month the law went into effect. The public health arguments criticising legislators for attempting to repeal the law ${ }^{5}$ reached its highest point in February 1998, after the California assembly voted to repeal the law, and before 


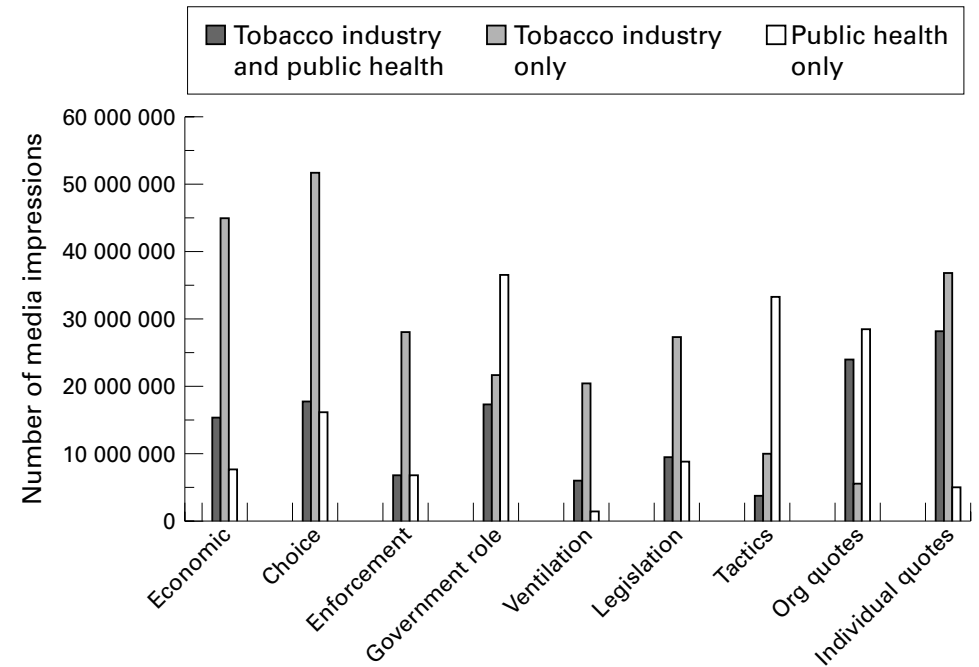

Figure 2 The tobacco industry viewpoint dominated coverage of the smokefree bar law in six of the nine argument categories. Public health dominated in the government role category, the tactics category (discrediting the tobacco industry), and organisational (org) quotes. Both viewpoints had different groups representing their stance on the issue: public health viewpoints were largely represented by organisations, and the tobacco industry viewpoint was represented by individual quotes.

the senate held a hearing that killed the repeal attempt and upheld the law.

ARGUMENTS

Figure 2 shows the number of media impressions that presented public health or tobacco industry arguments. The argument used most frequently by the tobacco industry was choice (freedom of choice, smokers rights, adult decision), followed by economics (bar law would hurt business), and enforcement (law was difficult to enforce). The argument used least often by tobacco industry was attacks on academic studies (studies about secondhand smoke, economics, or the bodies that performed these studies).

The arguments used most frequently by the public health groups differed from the tobacco industry's most frequent arguments. The most frequent public health argument was government role (government needs to protect workers from secondhand smoke). The second most used argument was attacking the tobacco industry's credibility (linking industry activity opposing the smokefree bar law to the industry's general pattern of disinformation). The third category of arguments by public health groups was choice (non-smokers rights and the majority of Californians supporting the smokefree bar law). Public health groups used the ventilation argument the least (countering tobacco industry claims that ventilation systems installed in bars would be adequate to protect workers from secondhand smoke).

BALANCE OF COVERAGE

Figure 2 also shows the balance of coverage. The tobacco industry perspective was represented more heavily in six of the nine categories (economics, choice/rights, enforcement, legislation, ventilation, and individual quotes). The public health perspective only lead the coverage in three categories (government role, and attacking credibility of the opposition, and organizational quotes).
REPRESENTATIVE VOICES

Public health dominated the organisational quotes. Organisational quotes were from voluntary organisations, academics and researchers, the state Department of Health Services, local health coalitions, departments of public health, and enforcement agencies. Tobacco industry organisations represented were infrequently cigarette manufacturers, but were more often bar/tavern alliances (both directly affiliated with the tobacco industry and not directly affiliated), the National Smokers' Alliance, and enforcement agencies that were not intending to enforce the law.

Individual quotes were skewed towards repealing the law. In $60 \%$ of the news articles that had individual quotes present, there were only quotes from individuals critical of the law; $31 \%$ of the news articles with individual quotes had quotes from both a pro-law, and a pro-repeal perspective, while only $9 \%$ of the news articles with quotes had quotes from only a pro-law perspective.

IMPACT OF NEWSPAPER SIZE

We assessed newspaper size using the Newspaper Association of America's circulation categories $^{20}$ : under $50000,50001-100000$, 100 001-250,000, and over 250000 . Six newspapers (Los Angeles Times, San Diego Union-Tribune, Orange County Register, San fose Mercury-News, San Francisco Chronicle, Sacramento Bee) in the six largest media markets (Los Angeles, San Diego, Orange County, San Jose, San Francisco, Sacramento) in the state had circulations exceeding 250000 .

The largest number of items appeared in the small papers (under 50000 circulation) (311). However, on a per paper basis, the smaller papers had 2.5 smokefree bar law items per paper, while the large newspapers (over 250000 circulation) had 16.2 smokefree bar law items per newspaper. The larger newspapers covered the debate over the smokefree bar law more intensively than the small newspapers.

There was not a consistent pattern in opinion articles with regards to newspaper size. All newspaper sizes had more anti-law editorials than pro-law editorials, except for large (100 001-250 000) newspapers (five pro-law, two anti-law editorials). The smallest (under 50000 circulation) and largest (over 250000 circulation) newspapers ran editorials about two to one against the law $(32 / 55,58 \%$ and $12 / 18,66 \%$, respectively).

In every newspaper size category, there were more letters to the editor published opposing the law (119) than supporting it (96). Midsize papers (50 000-100 000 circulation) had the greatest number of pro-law letters to the editor (29), but also the greatest number of anti-law letters to the editor (38).

PROXIES FOR TOBACCO CONTROL SENTIMENT We wanted to assess whether the presence of an existing local tobacco control ordinance was related to opinions reflected in local print media coverage, measured by the number of media impressions (defined by the number of 
opinion items in a paper, multiplied by the circulation of the paper for all papers published in the same locality) for each locality. We divided general workplace (not including restaurants)

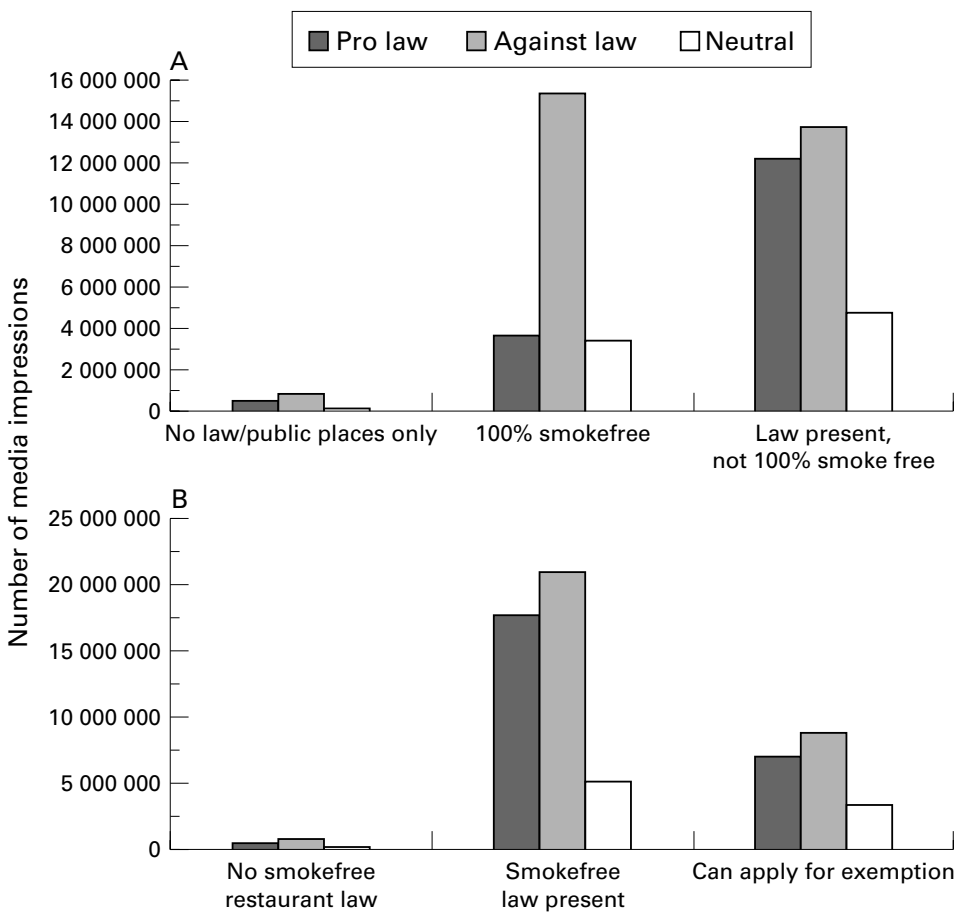

Figure 3 (A) Despite the local smokefree workplace laws present, communities with $100 \%$ smokefree workplace laws had more opinion items against the smokefree bar law than supporting the law. Communities with no law/public places law or a smokefree workplace law that was not $100 \%$ smokefree also had more opinion items against the law. (B) For restaurants, communities with $100 \%$ smokefree restaurant laws had the most opinion items, but again, there were more items against the law than pro-law. Communities with no laws or with exemptions followed a similar pattern.

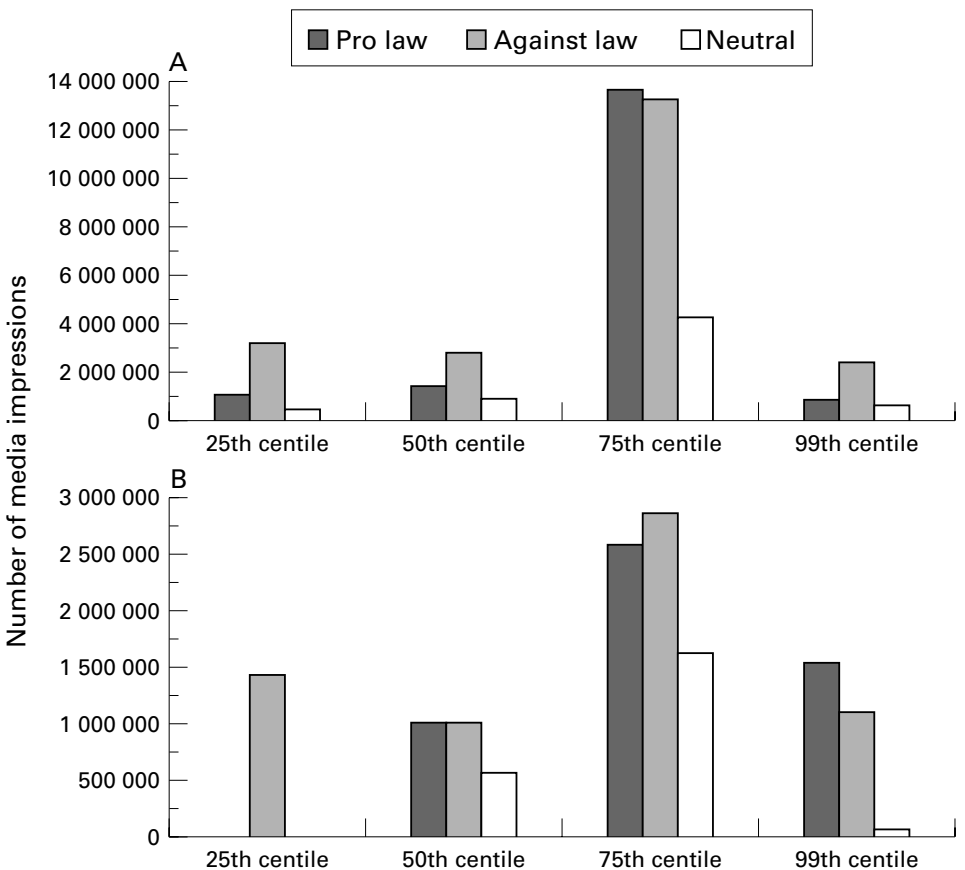

Figure 4 There was no systematic relation between community sentiment against the tobacco industry, as expressed in the vote against Proposition 188, and opinion items related to the smokefree bar law. (A) Communities in the 75th centile regarding percentage of the community voting against Proposition 188 in 1994 was the only group to have more pro-law letters to the editor as opposed to against law. (B) This pattern changed for editorials where only communities in the 99th centile had more editorials present in community papers that were pro-law rather than against law. local clean indoor air laws into three categories: no law or only public/government places, which would constitute a weak law; law present, not $100 \%$ smokefree, which meant that there were exceptions to the law, and would constitute the middle ground; $100 \%$ smokefree, which is a strong law. Regardless of the presence or strength of the local clean indoor air law, there were more opinion items published against the law than for the law (fig 3A). The largest disparity was in localities with $100 \%$ smokefree workplace laws.

Local clean indoor air laws dealing with restaurants were divided into three categories: no law, laws in which restaurants can apply for an exemption, representing the middle ground, and smokefree laws with no exemptions (strong law). As with general clean indoor air laws, more opinion items were published opposing the state smokefree bar law than supporting it, independent of the presence and strength of an existing local smokefree restaurant law (fig 3B). Thus, the community support that presumably existed in order to pass the local clean indoor air law did not seem to affect media presentation of local opinions on the state law.

We also assessed local tobacco control sentiment by examining the percentage of each locality voting against Proposition $188 .^{21} \mathrm{We}$ compared the number of pro-law, anti-law, and neutral media impressions from publication of letters to the editor and editorials on the smokefree bar law to the quartile of the localities' vote against Proposition 188 (with higher quartiles indicating stronger anti-tobacco sentiment). There was no systematic pattern between the local vote and letters to the editor and op-eds (fig 4A) or editorials (fig 4B) on the smokefree bar law, with most published opinion items opposing the law. However, it was interesting to note that for the localities in the lowest quartile of voting against Proposition 188, only negative editorials were present in the newspapers that served those communities.

\section{Discussion}

Despite strong public support for the smokefree bar law as evidenced in several public opinion polls ${ }^{5}$ and the resounding defeat of Proposition 188 a few years earlier, the tobacco industry claims dominated the print media coverage of the smokefree bar law. Nevertheless, public health advocates were able to convey the purpose of the law and their messages sufficiently to keep the smokefree bar law intact.

The tobacco industry used its usual arguments ${ }^{2}$ that the implementation of the smokefree bar would not work, restricted smokers' rights and freedom of choice, would have negative economic impacts on bars, and would not be enforceable. News articles used quotes from bartenders, bar owners, and individuals in bars to oppose the law. The tobacco industry also introduced a non-traditional category, called patron habits. Individuals were quoted as saying "Drinking and smoking just go together" and perpetuating the idea that it 
does not want public health forces to change the accepted cultural norm. Coverage of the smokefree bar law was dominated by tobacco industry issues. In no argument category did balanced coverage predominate.

To disseminate their message, the tobacco industry used public relations firm Burson Marsteller to create press releases for the media and legislators, organise press conferences featuring bar owners opposed to the law, and disseminate information through its National Smokers Alliance. ${ }^{516}$ Public health groups did not have the extensive media resources that the tobacco industry did to generate coverage, but were often sought out by newspapers for quotes and information, and wrote op-eds and letters to the editor in support of the smokefree bar law. While the tobacco industry received more favourable coverage overall, public health groups were also a substantial presence in the public debate.

Public health groups stuck to the message that the purpose of the law was to protect the health and safety of bar workers in California and the need to provide bar employees the same protection every other worker in the state enjoyed. ${ }^{5}$ Public health groups were also able to refute tobacco industry claims of economic hardship and freedom of choice by utilising public opinion surveys, published research, both economic and scientific, as well as citing the success of the state smokefree workplace law in general workplaces and restaurants since those provisions went in to force in 1995.

In addition, examining the frequency that items appeared in newspapers regarding the smokefree bar law, there was an immediate decline in items published shortly after the law was in effect, and the state legislature decided to table a major repeal effort and uphold the law. Although the tobacco industry claimed that the smokefree bar law would cause undue financial hardship to bars, be difficult to enforce, and strip adults of their freedom of choice, it seemed that there was a short adjustment period to the new law, after which the public accepted the change in the bar environment around the state.

Our study did not include advertisements that appeared in the print media. The tobacco industry publishes advertisements promoting smoking and bar promotions and the tobacco control groups published a series of opinion leader advertisements in newspapers likely to be read by opinion leaders (Sacramento Bee and the New York Times Western Edition) that called attention to the tobacco industry's attempts to repeal the law and calling on members of the legislature to uphold the law. ${ }^{5}$ These advertisements may have an impact on the public and legislative perception of the smokefree bar law.

Opinion pieces published in the newspapers did not match public sentiment regarding smokefree bar law. Polling by the state Department of Health Service, the American Cancer Society, and the Los Angeles Times ${ }^{22-27}$ all reflected high public support for the law. The disparity in this situation could be the result of

\section{What this paper adds}

While there have been several studies of media coverage of debates before passage of tobacco control legislation, no one has studied the public debate after the law goes into effect. This paper assesses California newspaper coverage of the state smokefree bar law during the seven months before, and one year following, the implementation of the law in January 1998. The analysis considered the number of items, trends in their timing, prevalence of different frames in the items, and correlation between antiand pro-law frames and level of local support for clean indoor air legislation. While anti-law arguments predominated in the media coverage, the level of pro-law arguments was high enough to sustain public and policy maker support for the law, which remains in effect.

This is the first article that analyses newspaper coverage of a tobacco control policy following implementation of that policy in order to provide feedback to public health practitioners on how well the policy is being supported in the media. California's smokefree bar law is so progressive that its success will likely determine the success of similar efforts throughout the USA. If not successfully implemented (and especially if overturned), the California experience might deter other states from taking similar action. In contrast, if successfully implemented (and not overturned), the California experience could provide strong support for other states to adopt similar policies. Understanding the way in which the law's implementation is covered in the print media provides important lessons for public health practitioners.

editorial bias, or simply reflect the view that it was better "news" to report on people who were unhappy about the new smokefree bar regulations. In the future, the tobacco control community can identify individual advocates and proponents of these laws who can act as media spokespersons to give the public the impression that clean indoor air laws have broad based public support.

One might think that a community organising around a previously passed local clean indoor air law would increase acceptance of the state law. This situation did not turn out to be the case: There was not a relationship between opinion items and previous experience with clean indoor air ordinances, region of the state, or voting on tobacco control ballot initiatives. There are several plausible explanations for this situation. First, the tobacco industry public relations effort to mobilise opposition to the smokefree bar law was the most visible aspect of the opinion items that appeared in newspapers around the state. Secondly, although public opinion polling demonstrated that the public supported the smokefree bar law, relatively few people felt moved to write and express this opinion. It is possible that health groups did 
not invest the same resources in generating letters to the editor and editorials with the same vigour as the tobacco industry did in generating opinion pieces in opposition to the law. Finally, the public considered the issue of smokefree public places settled with the defeat of Proposition 188, and felt the law was secure.

Several of the larger newspapers in California have staff writers and reporters that have covered tobacco control issues for some time, particularly the California Tobacco Control Program, and so have reporters who have developed expertise in tobacco issues. Smaller newspapers often rely on wire services or the larger newspapers for national stories, and reporters are more likely concerned with community events or occurrences. It did not appear that there was a systematic difference between news or opinion coverage in the large newspapers (Los Angeles Times, Sacramento Bee, San Diego Union-Tribune, Orange County Register, San Fose Mercury-News, San Francisco Chronicle) who had reporters who regularly covered tobacco compared to the smaller local newspapers.

The tobacco industry's public relations effort was successful in generating media coverage sympathetic to the tobacco industry's position on the smokefree bar law. Nevertheless, public health advocates were able to achieve enough coverage to prevent the law from being weakened or repealed.

We thank Matthew LeVeque of Rogers and Associates and the Tobacco Control Section of the California Department of Health Services for providing the results of the clipping service and Caroline Fichtenberg for comments on the manuscript. This work was supported by National Cancer Institute Grant CA-61021.

1 Macdonald H, Glantz, SA. Political realities of statewide smoking legislation: the passage of California's Assembly smoking legislation: the passage of Calif

2 Glantz S, Balbach E. Tobacco war: inside the California battles. Berkeley, California: UC Press, 2000.

3 Macdonald H, Aguinaga, S, Glantz, SA. The defeat of Philip Morris' 'California Uniform Tobacco Control Act'. Am F Public Health 1997;87:1989-96.

4 Magzamen S, Glantz S. Turning the tide: tobacco industry political influence and tobacco policy making in Californi 1997-1999. San Francisco, California: Institute for Health Policy Studies, School of Medicine, University of Calfornia, San Francisco, September 1999.

5 Magzamen S, Glantz S. The new battleground: California's experience with smokefree bars. Am F Public Health (in press) 6 Monardi F, Balbach E, Aguinaga S, et al. Shifting Allegiances: tobacco industry political expenditures in Carch 1996. San Francisco, California: Institute for Health Policy Studies, University of California, San FranHealth Policy Studie, April 1996.

7 Balbach E, Monardi F, Fox B, et al. Holding government accountable: tobacco policy making in California, 1995 - 1997. San Francisco, California: Institute for Health Policy Studies, University of California, San Francisco, June, 1997.

8 Jacobson P, Wasserman, J, Raube, K. The political evolution of anti-smoking legislation. Santa Monica, California: RAND, 1992.

9 Jacobson P, J Wasserman. Tobacco control laws: implementation and enforcement. Santa Monica, California: RAND, 1997.

10 Lima J, Siegel M. The tobacco settlement: an analysis of newspaper coverage of a national policy debate, 1997-98. newspaper coverage of a nation

11 Wallack L, Dorfman L, Jernigan D, et al. Media advocacy and public health: power for prevention. Newbury Park, California: Sage Publications, 1993

12 Iyengar S. Is anyone responsible?: How television frames political issues. Chicago: University of Chicago Press, 1991.

13 Menashe C, Siegel M. The power of a frame: an analysis of newspaper coverage of tobacco issues-United States, 1985-1996. Fournal of Health Communication 1998;3:30725 .

14 Cardador M, Hazan, AR, Glantz, SA. Tobaco industry smokers' rights publications: a content analysis. Am f Public Health 1995;85:1212-17.

15 Stauber J, Rampton S. Toxic sludge is good for you. Monroe, ME: Common Courage Press; 1995.

16 Americans for Nonsmokers' Rights Foundation. National Smokers Alliance: exposed. Berkeley, California: Americans for Nonsmokers' Rights. October 1998

17 Burrelle's Information Service. Press clipping service coverage profile. Livingston, New Jersey: Burrelle's Information Service, 2000.

18 Gale Research. Gale directory of publications and broadcast media. Detroit, Michigan: Gale Research. 1995.

19 Lacy S, Riffe D. Sampling error and selecting intercoder reliability samples for nominal content categories. Fournalism and Mass Communications Quarterly 1996;73:963-73.

20 Newspaper Association of America. Facts about newspapers, 1999. Vienna, Virginia: Newspaper Association of America, 1999. Report No. http://www.naa.org/info/ facts99.index.htm

21 Klink A, D'Onofrio, C, Emanuels, K, et al. Implementation of $A B$ 13: the impact of social will on tobacco control in California cities. Sacramento, California: California Healthy Cities and Communities, Center for Civic Partnership. March 1999.

22 American Cancer Society California Division. Smoke-free workplace law public opinion poll. Walnut Creek, California: Charlton Research Company. 25 March 1998.

23 California Department of Health Services. A survey of california adults age 21 or older about smoking policies and smoke-free bars. San Francisco, California: Field Research Corporation, July 1997.

24 California Department of Health Services. Smoke-free bars follow-up survey. San Francisco, California: Field Research follow-up survey. San Francisce

25 California Department of Health Services. A survey of california bar patrons about smoking policies and smoke-free bars. San Francisco, California: Field Research Corporation, 24 February-2 March 1998

26 LA County Health Department. Bar patrons in LA County overwhelmingly support smoke-free bars. San Francisco, California: Communication Sciences Group. February 25, 1998.

27 Morain D. Bar Smoking ban gets wide backing. Los Angeles Times 27 May 1998; p A3. 